\title{
South Indian Tamil Cinema's Influence on Sri Lankan Tamil Filmmakers
}

\author{
R. Joel Jairus, Sivapriya Sriram
}

\begin{abstract}
Department of Languages \& Communication Studies, Faculty of Communication and Business studies, Trincomalee Campus, Eastern University of Sri Lanka.

Received: 09 Nov 2020; Received in revised form: 12 Dec 2020; Accepted: 21 Dec 2020; Available online: 28 Dec 2020 (C2020 The Author(s). Published by Infogain Publication. This is an open access article under the CC BY license (https://creativecommons.org/licenses/by/4.0/).
\end{abstract}

\begin{abstract}
The research seeks to find out the South Indian Tamil cinema's influence on Sri Lankan Tamil filmmakers. In addition to that, the study examines the nature of the South Indian Tamil cinema's influence on Sri Lankan Tamil filmmakers, the reasons for the South Indian Tamil cinema's influence on Sri Lankan Tamil filmmakers and the recommendation to overcome from the South Indian Tamil cinema's influence on Sri Lankan Tamil filmmakers. In order to carry out the objectives of the research, survey methodology was employed. Primary data were collected through in-depth interviews.The research found out thatMajority of the Sri Lankan Tamil film directors are influenced by the South Indian Tamil cinema in their film making style and their main purpose of filmmaking is entertainment rather than social messages. The civil war in Sri Lanka, Migrations of Sri Lankan Tamil artists, Loss of Sri Lankan Tamil studios, Sri Lankan Tamil media's attractions towards South Indian Tamil cine field, a smaller number of Sri Lankan Tamil audience compared to South Indian Tamil audiences are the basic reasons for the Sri Lankan Tamil filmmakers to be influenced by the South Indian Tamil cinema.
\end{abstract}

Most of the Sri Lankan Tamil short film directors like to make entertaining short films in South Indian Tamil movie style and dialogue delivery as majority of the Sri Lankan Tamil audience enjoy comedy, romantic and fantasy genre short films rather than social content oriented short films. Currently most of the Sri Lankan Tamil films are produced by Diaspora Sri Lankan Tamils and majority of them are willing to spend money on commercial south Indian style cinema. Majority of the south Indian filmmakers are professionally sound and they have completed filmmaking courses. Rest of the South Indian directors have worked as assistant directors under famous south Indian Tamil directors who gave successful movies but Sri Lankan Tamil directors have no any Tamil institutes in Sri Lanka to study filmmaking.

Theatre owners who screen the South Indian movies should give specific times or days for Sri Lankan movies since Sri Lankan Tamil filmmakers are requested to screen their films when there are no any south Indian films running in the theatres. The Sri Lankan Tamil media should give equal support to the Sri Lankan filmmakers like they do for South Indian artist. Sri Lankan media should encourage the Sri Lankan Tamil short filmmakers with short film competitions shows like "NaalayaIyakkunar" of Kalaignar TV which has produced more young talents as the filmmakers in South Indian film industry. "Osmodeus" a Tamil short film directed by Jacob L Jeroshan from Batticaloa, Sri Lanka was screened in Cannes film festival 2018. But none of the Sri Lankan media had covered this news.

The study recommends that the Sri Lankan Tamil directors are in need to make the movies which up to the standards of South Indian Tamil movies. As Sri Lankan setting has many stories, The Sri Lankan Tamil directors should have a courage to try something new rather than following usual commercial methods of filmmaking. Sri Lankan Tamil filmmakers should make movies which are in the standard to screen in the International film festivals where they are able to earn international producers and movie distributors. Sri Lankan Tamil directors should come out of the "Eezham" concept of scripts since many directors already have made on that. Media students and movie lovers should try to make groups, associations, or workshop on world cinema which help the filmmakers to get more knowledge of film language and filmmaking. Tamil 
filmmaking institute should be implemented in Sri Lanka to learn professional way of filmmaking and professional acting. An association should be implemented to approach the needed things easily for filmmaking and guide the artists with rules and regulation. Sri Lankan Tamil directors should do need analysis research among Sri Lankan Tamil audience to understand their interest and expectation on Sri Lankan Tamil movies.

\section{Keywords-Influence, Sri Lankan Tamil Cinema, South Indian Tamil cinema, Short films, Survey method.}

\section{BACKGROUND OF THE STUDY}

"The cinema is not an art which films life: the cinema is something between art and life. Unlike painting and literature, the cinema both gives to life and takes from it, and I try to render this concept in my films. Literature and painting both exist as art from the very start; the cinema doesn't". says the author of "Godard", Richard Roud (1970).

Sri Lankan cinema encompasses the films made in Sri Lanka. It is a fledgling industry that has struggled to find a footing since its inauguration in 1947 with KadawunuPoronduwa produced by S.M. Nayagam of Chitra Kala Movietone. Sri Lankan films are usually made in the Sinhalese language, as well as in Tamil Language. In the first nine years most films were made in South India and followed the conventions of Indian cinema. Studio shooting was the norm, with Indian style sets erected in film studios. Even though it is popularly held that Rekava, made in 1956 by pioneer director Lester James Peries, was the first Sinhala film to be shot completely out of studio, it was really the film "GambadaSundari", made in 1950 which was the first film shot outside studios. (ThampiAyyaThevathas)

It was also the first Sri Lankan film where, like in "Rekawa", the dialogue was recorded on the spot. In 1964, Lester James Peries again contributed to the development of Sri Lankan cinema with Gamperaliya which was the first Sinhala film to feature no songs and like Rekava shot completely outside the studio. It garnered massive praise for portraying Sinhala culture in a realistic manner and was hailed by critics and audiences alike.

Sri Lankan Tamil cinema, the Tamil language film industry in Sri Lanka, has remained relatively small with fewer than 100 films produced. The Tamil film industry in Sri Lanka is not as developed as Sinhala cinema or its Indian counterpart, the Tamil cinema of Kodambakkam, Chennai, Tamil Nadu. There is a lot of competition from Tamil films from Tamil Nadu, India as well as obstacles from the long run ethnic civil war in Sri Lanka. Tamils contributed significantly to Sinhala cinema as well as Indian Tamil cinema. Only a few Tamil language films were produced in the Northern Province of Sri Lanka. Earlier Tamil movies produced were all most destroyed or unrecovered due to civil war. A Sinhalese film was dubbed in Tamil in December 29, 1951. The movie Samuthayam (Society), an adaptation of C.N. Annadurai's Velaikkari was made in $16 \mathrm{~mm}$ and Technicolor. It was shown in 1962 and 1963. Thottakkari (Plantation Woman), released on March 28, 1962, was the first Sri Lankan Tamil film in the standard $35 \mathrm{~mm}$ format.

So far there are 36 Tamil films have been made. There are few posters and advertisements of Sri Lankan Tamil films since 1960s, but most of the films had been dropped. Many Tamil Films made by LTTE also are concealed. The Tamil Films which were produced here are restricted in film screenings. Those films were shown only one or two times and had not distributed to the theatres in other areas. Though a specific group of audience are ready to welcome the Sri Lankan Tamil Films, but the directors are failed to impress the Sri Lankan Audience. Sri Lankan directors mostly try to imitate south Indian films' style.(ThampiAyyaThevathas, 2018).

Since no much formal studies have so far been undertaken for the South Indian Cinema's influence on Sri Lankan Tamil filmmakers, the aim of the present study is to find out the nature of the influence of South Indian Cinema on Sri Lankan Tamil filmmakers, Reasons for the influence of South Indian Cinema on Sri Lankan Tamil filmmakers and Recommendations to overcome theinfluence of South Indian Cinema on Sri Lankan Tamil filmmakers.

\section{METHODOLOGY}

Research Methodology is a way to find out the result of a given problem on a specific matter or problem that is also referred as research problem. In Methodology, researcher uses different criteria for solving/searching the given research problem. Different sources use different type of methods for solving the problem. If we think about the word "Methodology", it is the way of searching or solving the research problem (Industrial Research Institute, 2010).

The present study has used survey method as the methodology to examine the research questions. Survey 
method is a descriptive method used for the collection of data from the representative sample of the target population(T.Mathiyazhagan\&Deoki Nandan, 2010).

The present study has used Personal in-depth interviews, which is one of survey methods to examine the research problem. As such the present study has used a total of 12 personal in-depth interviews as follows,

- Five interviews of Sri Lankan Tamil short film directors

- Five interviews of Sri Lankan Tamil feature film directors

- Two interviews of Sri Lankan Tamil film critiques

The samples for the present study have been selected through purposive non-random sampling method.

A purposive sample, also referred to as a judgmental or expert sample, is a type of nonprobability sample. The main objective of a purposive sample is to produce a sample that can be logically assumed to be representative of the population. This is often accomplished by applying expert knowledge of the population to select in a non-random manner a sample of elements that represents a cross-section of the population (Paul J. Lavrakas 2008).

This study was conducted withTen Tamil filmmakers in Sri Lanka andtwoTamil Film critiques in Sri Lanka.

\section{RESULTS AND DISCUSSION}

The present study has examined the problem identified and collected data through survey method and the data has been categorized under the following titles and it is as follows,

\subsection{Nature of the influence of South Indian Cinema on Sri Lankan Tamil filmmakers.}

According to the findings, Sri Lankan film Industry has started to follow the Indian cinema from the time of its inception. South Indian Tamil film industry is a huge processing industry which produces more than 200 plus films per year. They have captured the largeraudience in India, Sri Lanka, Malaysia, Singapore and other countries where majority of the Tamil people live. Hence, the influence of South Indian Tamil Cinema industry on Sri Lankan Tamil films and there audience is obvious due to its larger scale production and distribution.

The study has found out that the influence of South Indian Tamil Cinema industry is visible in the theme, film making, storytelling and screenplay of the Sri Lankan Tamil cinema. $80 \%$ of the Tamil feature film directors and $60 \%$ of the Tamil short film directors stated that,they are influenced by South Indian Tamil cinema in filmmaking. $70 \%$ of the Sri Lankan Tamil directors stated that their main purpose of filmmaking is entertainment rather than addressing a social issue in films and make the audience more frustrated.

Majority (70\%) of the Sri Lankan Tamil directors stated that they have grown up by watching South Indian Tamil movies and they are addicted to the theatre celebrations for the big south Indian heroes' movies.Majority $(60 \%)$ of the Sri Lankan Tamil short filmmakers stated that their commercial type of short films in comedy, fantasy and romantic genres have been appreciated by the Sri Lankan Tamil audience than their social contented short films.

Film critiques stated that due to Civil war in Sri Lanka, The Sri Lankan Tamil film studios and industry were demolished and media started to give priority to South Indian Tamil films, songs, soap operas and reality show. It has attracted the Sri Lankan Tamil audience for many eras. Therefore, the Sri Lankan Tamil directors are trying to get the Sri Lankan Tamil audience's attraction by making movies in South Indian style.

The study has found out that, Sri Lankan Tamil audience are attracted towards commercial movies more than art films. Thampiayyathevathasstated that film Ponmani(1976) was failed in theatres as it spoke about the caste problems in Jaffna and the audience made fun of the dialogue delivery of the actors. The film had no glamour scenes which were expected by the audience.

However, $20 \%$ of the Tamil feature film directors and $40 \%$ of the Tamil short film directors have stated that they are not influenced by South Indian Tamil cinema in filmmaking and they are trying to make Sri Lankan Tamil films in their own style which suitable for the Sri Lankan Tamil audience. Further they stated, it is their responsibility to address the social issues in their films and films should make impacts in the audience mind. The Sri Lankan Tamil short film directors who were not influenced by the South Indian Tamil cinema stated that even though their short films were not much appreciated by the Sri Lankan Tamil audience, they got recognitions in several film festivals. Further they said rather than entertainment of local audiences they would like to bring the Sri Lankan traditions, culture, problems, politics in the international platforms through their productions.

\subsection{Reasons for the influence of South Indian Cinema on Sri Lankan Tamil filmmakers}

The Study has found out that, the Civil war in Sri Lanka is one of the reasons for the influence of South Indian 
Cinema on Sri Lankan Tamil filmmakers. Film critiques stated that during the civil war, most of the Sri Lankan filmmakers have displaced and migrated to other countries and government didn't take any actions to build-up the Sri Lankan Tamil industry. Therefore, Sri Lankan Tamil audience are attracted towards South Indian Tamil cinema.

The Study has further found out that, the lack of film producers for Sri Lankan Tamil films is one of the reasons for the influence of South Indian Cinema on Sri Lankan Tamil filmmakers.

Famous South Indian film productions companies such as LYCA and Ayngaran are owned by Sri Lankans. But they have never invested money on Sri Lankan Tamil films. Currently most of the Sri Lankan Tamil films are produced by Diaspora Sri Lankan Tamils. Majority of the diaspora producers are willing to spend money on commercial south Indian style cinema as they need to recollect the money.

The study has further found out that, the smaller number of audience availability for Sri Lankan Tamil cinema is one of the reasons for the influence of South Indian Cinema on Sri Lankan Tamil filmmakers. The total population of Tamils in Sri Lanka is comparatively less than Sinhalese live in Sri Lanka. Therefore, Sri Lankan Tamil filmmakers have limited numbers of audience in Sri Lanka. They are not able to collect the money that they have invested in filmmaking with these limited number of audiences who prefer to watch South Indian Tamil movies more than Sri Lankan Tamil movies.

The study has further found out that the Sri Lankan Tamil directors are not able to compete with South Indian Tamil industry since the South Indian industry is very big in business and productions. Therefore, the Sri Lankan Tamil directors are willing to make South Indian style movies to attract more audiences.

$70 \%$ of the Sri Lankan filmmakers have stated that they don't like to use the nativity dialogue delivery in the movies since most of the Sri Lankan Tamil audience are not able to understand the different areas' slangs and they are used to South Indian movie dialogue delivery style. Further they stated that Sri Lankan Tamil audience expect fast screenplay, love, comedy, fights, songs, glamour in the Sri Lankan Tamil movies to enjoy.

The study has further found out that, the less amount of support given by Sri Lankan Tamil media to Sri Lankan Tamil cinema is one of the reasons for the influence of South Indian Cinema on Sri Lankan Tamil filmmakers. Most of the Sri Lankan Tamil Directors (70\%) stated that Sri Lankan Tamil media are not supporting the Sri Lankan Tamil filmmakers and the Sri Lankan Tamil media mostly telecast south Indian movies, songs and soap operas.
"Osmodeus" a Tamil short film directed by Jacob L Jeroshan from Batticaloa, Sri Lanka was screened in Cannes film festival 2018. But none of the Sri Lankan media had covered this news.

The research has found out further that Sri Lankan theatre owners support South Indian films rather than Sri Lankan Tamil films. Sri Lankan Tamil filmmakers are requested to screen their films when there are no any south Indian films running in the theatres.

Thampi Ayya Devathas, the film critique stated that he has watched a Sri Lankan Tamil movie named "Manasukul Mazhaicharal" talks about school love. The movie was appreciable since it was made in Sri Lankan native style and with native dialogue delivery. And he further stated that he has watched another Tamil commercial type movie named "Pahadai 16"from Sri Lanka which talks about rowdies and heroism. But the movie didn't have a good story plot.

Furtherthe research has found out that majority of the south Indian filmmakers are professionally sound and they have completed filmmaking courses. Rest of the South Indian directors have worked as assistant directors under famous south Indian Tamil directors who gave successful movies.

Sri Lankan Tamil directors have no any Tamil institutes in Sri Lanka to study filmmaking. Therefore, they find no choices rather than following south Indian Filmmaking style.

3.3 Recommendations to overcome the influence of South Indian Cinema on Sri Lankan Tamil filmmakers

The study has found out that making the movies up to the standard of South Indian Tamil cinema is one of therecommendations to overcome the influence of South Indian Cinema on Sri Lankan Tamil filmmakers. The film critiques stated Sri Lankan Tamil and Sinhala movies are influenced by the Indian movies from the very beginning. Most of the Sri Lankan Tamil directors tried to remake South Indian Tamil movies in Sri Lanka and were failed in box office.

Komalikal and Komali Kings are well received by the Sri Lankan Tamil audience as they are Sri Lankan native comedy movies. The Sri Lankan Tamil directors are in need to make the movies which up to the standards of South Indian Tamil movies.

Director Balumahendra from Sri Lanka went to South Indian Tamil industry and made many critically acclaimed movies in non-commercial ways. The Sri Lankan Tamil directors should have a courage to try something new rather than following usual commercial methods of 
filmmaking. As Sri Lankan setting has many stories, the Sri Lankan Tamil Directors should make the movie on their native.

The study has found out that making the movies up to the standard to screen in International film festival is one of therecommendations to overcome the influence of South Indian Cinema on Sri Lankan Tamil filmmakers. Thampi Ayya Devathas, the film critique agreed that rather than following South Indian filmmaking style, Sri Lankan Tamil filmmakers should make their own unique way of filmmaking which is in the professional standard. The directors should learn to make films with interesting plots which have the settings in Sri Lanka along with particular places' dialogue slangs. further they sated rather thancompeting with Indian cinema, Sri Lankan Tamil filmmakers should make movies which are in the standard to screen in the International film festivals. Screening in the international film festivals will help the directors to earn international producers and movie distributors. It will help them to capture the international media's attention towards the movie even though the local media don't support us.

Uma Varatharajan, the film critique stated that a movie is made for the large audience. If a movie is screened only for few people in a film festival with limited audience or screened only in one or two theatres it cannot be considered as movie. A movie should reach more people. Therefore, theatre owners who screen the South Indian movies should give a specific times or days for Sri Lankan movies. The Sri Lankan Tamil media should give equal support to the Sri Lankan filmmakers like they do for South Indian artists. Many young Tamil directors got chances to make films in South Indian industry after the successful short film competition show "Naalayalyakkunar" done by Kalaignar TV. Sri Lankan media also should encourage the Sri Lankan Tamil short filmmakers with such short movie competitions and it will give big exposure to the Sri Lankan Tamil filmmakers.

Further he stated that Sri Lankan Tamil directors should come out of the "Eezham" concept of scripts since many directors already have made on that. Sri Lankan Tamil directors should try new plots too.

Filmmakers, Media students and movie lovers should try to make groups, associations, or workshop on world cinema. By watching world cinema, the filmmakers will get more knowledge of film language and filmmaking.

The film critiques and Sri Lankan Tamil Filmmakers agreed that Tamil filmmaking institute should be implemented in Sri Lanka to learn professional way of filmmaking and professional acting. An association should be implemented to approach the needed things easily for filmmaking and guide the artists with rules and regulation.

Sri Lankan Tamil directors should do need analysis research among Sri Lankan Tamil audience to understand their interest and expectation on Sri Lankan Tamil movies.

\section{CONCLUSION}

The study concludes that, Majority of the Sri Lankan Tamil film directors are influenced by the South Indian Tamil cinema in their film making style and their main purpose of filmmaking is entertainment rather than social messages. The civil war in Sri Lanka, Migrations of Sri Lankan Tamil artists,Loss of Sri Lankan Tamil studios, Sri Lankan Tamil media's attractions towards South Indian Tamil cine field, No producers to invest,a smaller number of Sri Lankan Tamil audience compared to South Indian Tamil audiences are the basic reasons for the Sri Lankan Tamil filmmakers to be influenced by the South Indian Tamil cinema.

Most of the Sri Lankan Tamil short film directors like to make entertaining short films in South Indian Tamil movie style and dialogue delivery as majority of the Sri Lankan Tamil audience enjoy comedy, romantic and fantasy genre short filmsrather than social content oriented short films.

Sri Lankan Tamil filmmakers who are not influenced by South Indian Tamil cinema in filmmaking, are trying to make Sri Lankan Tamil films in their own style which suitable for the Sri Lankan Tamil audience as they believe it is their responsibility to address the social issues in their films and films should make impacts in the audience mind.

LYCA owned by a Sri Lankan Tamil lives in British produces high budget Tamil films in India rather than Sri Lanka. Currently most of the Sri Lankan Tamil films are produced by Diaspora Sri Lankan Tamils and majority of them are willing to spend money on commercial south Indian style cinema.

Majority of the south Indian filmmakers are professionally sound and they have completed filmmaking courses. Rest of the South Indian directors have worked as assistant directors under famous south Indian Tamil directors who gave successful movies but Sri Lankan Tamil directors have no any Tamil institutes in Sri Lanka to study filmmaking. Therefore, they find no choices rather than following south Indian Filmmaking style.

A movie should reach more people. Sri Lankan Tamil filmmakers are requested to screen their films when there are no any south Indian films running in the theatres. Therefore, theatre owners who screen the South Indian movies should give specific times or days for Sri Lankan 
movies. The Sri Lankan Tamil media should give equal support to the Sri Lankan filmmakers like they do for South Indian artist. Sri Lankan media should encourage the Sri Lankan Tamil short filmmakers with short film competitions shows like "Naalayalyakkunar" of Kalaignar TV which has produced more young talents as the filmmakers in South Indian film industry.

"Osmodeus" a Tamil short film directed by Jacob L Jeroshan from Batticaloa, Sri Lanka was screened in Cannes film festival 2018. But none of the Sri Lankan media had covered this news.

\subsection{Recommendation}

The Sri Lankan Tamil directors are in need to make the movies which up to the standards of South Indian Tamil movies as Komalikal and Komali Kings are well received by the Sri Lankan Tamil audience as they are Sri Lankan native comedy movies.

Director Balumahendra from Sri Lanka went to South Indian Tamil industry and made many critically acclaimed movies in non-commercial ways. As Sri Lankan setting has many stories, The Sri Lankan Tamil directors should have a courage to try something new rather than following usual commercial methods of filmmaking.

Sri Lankan Tamil filmmakers should make movies which are in the standard to screen in the International film festivals where they are able to earn international producers and movie distributors. Sri Lankan Tamil directors should come out of the "Eezham" concept of scripts since many directors already have made on that.

Media students and movie lovers should try to make groups, associations, or workshop on world cinema which help the filmmakers to get more knowledge of film language and filmmaking. Tamil filmmaking institute should be implemented in Sri Lanka to learn professional way of filmmaking and professional acting. An association should be implemented to approach the needed things easily for filmmaking and guide the artists with rules and regulation. Sri Lankan Tamil directors should do need analysis research among Sri Lankan Tamil audience to understand their interest and expectation on Sri Lankan Tamil movies.

\section{REFERENCES}

[1] Elizabeth T. Giwa (2014) Nollywood: A Case Study of the Rising Nigerian Film Industry- Content \& Production retrieved on 9, July, 2018 from https://opensiuc.lib.siu.edu/cgi/viewcontent.cgi?article $=166$ $7 \&$ context $=$ gs_rp

[2] Faber, Liz \& Walters, Helen (2003). Animation Unlimited: Innovative Short Films Since 1940. London: Laurence King, in association with Harper Design International. ISBN 185669-346-5

[3] Gerring, John (2018) Organizing your social science research paper: Writing a case study Retrieved on 18.08.2018 from http://libguides.usc.edu/writingguide/casestudy

[4] International Journal of Humanities and Social Science ISSN 2220-8488 (Print), 2221-0989 Retrieved on 15 August 2018

[5] King, Geoff (2002). New Hollywood Cinema: An Introduction. New York: Columbia University Press. ISBN 0-231-12759-6

[6] Michelson, A. (1995). What Is Cinema? Performing Arts Journal, 17(2/3), 20-29. Retrieved on 10 November 2020 From https://www.jstor.org/stable/3245771?seq=1

[7] Paul J. Lavrakas (2008). Encyclopedia of Survey Research Methods, SAGE research methods, Retrieved on 11 November 2020

Fromhttps://methods.sagepub.com/reference/encyclopediaof-survey-research-

methods/n419.xml\#: :text=A\%20purposive\%20sample\%2 C\%20also\%20referred,a\%20type\%20of\%20nonprobability $\%$ 20sample.\&text $=$ In $\% 20$ probability $\% 20$ sampling $\% 2 \mathrm{C} \% 2$ 0each\%20element,of\%20a\%20random\%20selection\%20pr ocedure.

[8] Prof.Dr. Werner Patzelt, (2016) Case study research and the Grounded theory approach Retrieved on 16 August 2018 from http://ipsa.sbe.metu.edu.tr/case-study-researchand-grounded-theory-approach

[9] Pamela Baxter., Susan Jack(2008), Qualitative Case study Methodology, The Qualitative Report, Retrieved on 16 August $2018 \quad$ From https://nsuworks.nova.edu/tqr/vol13/iss4/2/

[10] Sue Soy (2006), The Case Study as a Research Method, Uses and Users of information, Retrieved on 14 August 2018 From https://www.ischool.utexas.edu/ ssoy/usesusers/1391d1b.ht $\underline{\mathrm{m}}$

[11] Thampiayya Devadas, (2000). Story of the Sri Lankan Tamil Cinema, Kaanthalagam.

[12] Thackway, Melissa (2003). Africa Shoots Back: Alternative Perspectives in Sub-Saharan Francophone African Film. Bloomington, IL: Indiana University Press. ISBN 0-85255576-8. 